The Polish Journal of the Arts and Culture. New Series 13

(1/2021): 51-66 [ARTYKUE]

DOI: $10.4467 / 24506249$ PJ.21.003.13730

\title{
Architektura podziałów. Przestrzeń walki klas w filmach Bonga Joon-ho Snowpiercer: Arka przyszłości i Parasite
}

\author{
Agnieszka KamrowsKa
}

\begin{abstract}
Streszczenie
Tekst jest próbą analizy filmów Snowpiercer: Arka przyszłości i Parasite koreańskiego reżysera Bonga Joon-ho w ujęciu socjologicznym. Teoretycznego zaplecza dostarczają pojęcia klasy społecznej i walki klas opisane przez Karola Marksa, następnie skorygowane przez Maxa Webera i dalej reinterpretowane przez Pierre'a Bourdieu. Posłużono się również koncepcją Aparatów Państwa autorstwa Louisa Althussera. Pojęcia te tworzą szkielet teoretyczny, w który wpisana została kwestia przestrzeni architektonicznej w analizowanych filmach. Bong Joon-ho umieszcza bohaterów w zamkniętych wnętrzach i stawia ich w sytuacji konfliktu klasowego, w którym muszą walczyć o przetrwanie lub awans społeczny. Stosując kategorie opisu przestrzeni, jak powierzchnia, zatłoczenie, uporządkowanie czy dostęp do światła słonecznego, twórca definiuje sytuację życiową bohaterów oraz ich motywację.
\end{abstract}

SŁowA KLUCzowe: walka klas, klasa społeczna, świat przedstawiony W filmie, Bong Joon-ho

Agnieszka Kamrowska, kulturoznawczyni, doktor nauk o sztuce, absolwentka filmoznawstwa na Wydziale Zarządzania i Komunikacji Społecznej UJ, gdzie obroniła pracę doktorską o cyberpunku w kinie Wschodu i Zachodu. Badaczka kinematografii dalekowschodnich, redaktorka serii Autorzy kina azjatyckiego (tom 1: 2010 - z prof. Alicją Helman, tom 2: 2015). Adiunkt w Instytucie Sztuki Mediów Uniwersytetu Pedagogicznego w Krakowie.

iD https://orcid.org/0000-0001-9474-9271

E-MAIL: agnieszka.kamrowska@up.krakow.pl 


\section{Wprowadzenie}

Reżyser Bong Joon-ho należy do najciekawszych twórców współczesnego kina, jego filmy biją rekordy popularności w rodzimej Korei, na całym świecie gromadzą liczną widownię, zdobywając kolejne laury na międzynarodowych festiwalach, z canneńską Złotą Palmą na czele. Swój sukces Koreańczyk zawdzięcza oryginalnej filmowej recepturze: kolażowi różnych konwencji gatunkowych połączonemu z autorskim komentarzem społecznym i wysokim poziomem realizacji. Formuła ta sprawdziła się w filmach kameralnych, ukazujących losy zwykłych ludzi: Szczekające psy nigdy nie gryzą (Flandersui gae, 2000), Zagadka zbrodni (Salinui chueok, 2006), Matka (Madeo, 2009), jak i w wypełnionym efektami specjalnymi The Host: Potwór (Gwoemul, 2006) czy superprodukcjach z międzynarodową obsadą: Snowpiercer: Arka przyszłości (Snowpiercer, 2013) i Okja (2017). „Niezależnie jednak, czy jest to intymna historia, czy kosztowny blockbuster, jego twórczość jest tematycznie spójna. Wykorzystując schematy i ikonografię kina gatunkowego, Bong kreśli portret Koreańczyków, zastanawiając się nad ich tożsamością, najnowszą historią kraju i wynikającymi z niej traumami i nierównościami” (Krasnowolski 2019, 42).

Zarówno jego filmy rozgrywające się we współczesnej Korei Południowej, jak i produkcje międzynarodowe przedstawiają ludzkość podzieloną na klasy według ekonomicznie zdeterminowanych kryteriów. W trzech ostatnich filmach Bonga podziały klasowe zostały przez reżysera przedstawione w niezwykle wyrazisty sposób, a na pierwszy plan wysuwa się wątek walki klas:

Zacząłem rozwijać ten pomysł [filmu podejmującego kwestie nierówności społecznych - przyp. A.K.] w 2013 roku. Problem, jakim jest polaryzacja ekonomiczna, czyli podział na bogatych i biednych, był wtedy mocno dostrzegalny w Korei, choć chyba nie w takim stopniu jak teraz. To zresztą temat uniwersalny, który dotyczy wszystkich krajów na świecie. Kiedy zacząłem myśleć o Parasite, pracowałem nad postprodukcją Snowpiercera: Arki przyszłości. On również odnosi się do różnic klasowych, zatem ten koncept kiełkował mi w głowie od dawna (Armata 2019, 45).

W wymienionych filmach najważniejszym przejawem różnic klasowych, i jednocześnie kluczową determinantą danej klasy społecznej, jest zajmowana przez nią przestrzeń, miejsce zamieszkania. Filmy Snowpiercer: Arka przyszłości i Parasite, choć zrealizowane w odmiennych poetykach, ukazują społeczną i ekonomiczną walkę klas jako batalię o przestrzeń do życia, zaś architektura owej przestrzeni odgrywa w obu filmach kluczową rolę. 


\section{Mikrokosmos pociągu}

Fabuła filmu Snowpiercer: Arka przyszłości wywodzi się z francuskiego komiksu Le Transperceneige Jacques'a Loba i Jean-Marca Rochette'a, z którego reżyser zaczerpnął wizję świata po zlodowaceniu wywołanym próbami zwalczenia skutków globalnego ocieplenia oraz pociąg mknący przez lodową pustynię, będący schronieniem dla niedobitków ludzkiej rasy. To dystopijny obraz niedalekiej przyszłości, gdzie inżynieria klimatyczna doprowadziła do ogólnoświatowej zagłady, z której ocaleli nieliczni. W filmie Bonga

resztki ludzkości przetrwały w zaplombowanym, mknącym dookoła globu nieprzerwanie od 17 lat pociągu. Panuje wyzysk. Lokomotywą kieruje despota. Uszeregowane wedle zamożności wagony niczym szczelnie zaplombowane sejfy uniemożliwiają swobodne poruszanie się pasażerom na samym dole drabiny społecznej. Wybucha bunt przeciwko wagonowej burżuazji, który przebiega zgodnie z regułami walki klasowej (Wróblewski, nd.).

W pociągu panują ustrój totalitarny i segregacja klasowa - najubożsi mieszkają w ostatnich wagonach, im bliżej lokomotywy tym większy komfort i dostatek pasażerów. Świat przedstawiony w filmie zredukowany jest do wnętrza pociągu, kamera rzadko ukazuje zamarznięty krajobraz za jego oknami. Sama kolejka zaś jest systemem zamkniętym, mikrokosmosem z hierarchicznie ustalonym porządkiem społeczno-przestrzennym. Tylne wagony zamieszkiwane są przez tzw. darmozjadów, których nie stać było na wykupienie biletu na pociąg, lecz wdarli się do niego, by ocalić życie. W zamkniętym ekosystemie pociągu gapowicze są więźniami, częściami zamiennymi, siłą roboczą niezbędną do obsługi uprawnionych pasażerów. Środkowe wagony klasy ekonomicznej przeznaczone są dla wyspecjalizowanych pracowników najemnych, którzy własną pracą odpłacają za przejazd pociągiem. W klasie pierwszej, ulokowanej w przedniej części składu, rezydują bogaci pasażerowie, których stać było na wykupienie kosztownego biletu zapewniającego im nie tylko ocalenie, ale i komfortowe życie w luksusie. Na czele znajduje się maszynownia kryjąca silnik pociągu i jego konstruktora - wynalazcę Wilforda (Ed Harris).

Każda z trzech sekcji pociągu: tylna, środkowa i przednia, jest przeznaczona dla określonej klasy społecznej definiowanej przez stan posiadania i przypisaną funkcję. Architektura wnętrza pociągu jest więc odzwierciedleniem hierarchicznej struktury społecznej pasażerów, zaś wygląd 
poszczególnych sekcji określa sytuację ekonomiczną danej klasy. Sekcja tylna pociągu pozbawiona jest okien, jej brudni mieszkańcy żyją stłoczeni w półmroku, gnieżdżąc się niczym szczury w klaustrofobicznym labiryncie rur, szmat i prowizorycznych legowisk. Ludzie z końcowych wagonów nie mogą się swobodnie przemieszczać, otrzymują racjonowaną żywność w postaci ciemnych proteinowych bloczków, nieświadomi, iż wytwarzane są one z karaluchów. Kiedy w proteście przeciwko nieludzkiemu traktowaniu wszczynają bunt, siłą próbują przedrzeć się na przód składu, gdzie w komforcie i dostatku egzystują pasażerowie lepszych klas. W swojej wędrówce na przód pociągu zbuntowani gapowicze odkrywają bar sushi, chłodnię pełną świeżego mięsa, bibliotekę, gabinet stomatologiczny, pracownię krawiecką, restaurację, salon piękności, basen, saunę i klub nocny - przybytki, w których bogaci podróżni pierwszej klasy mogą zaspokajać swoje potrzeby i zachcianki.

Na szczególną uwagę zasługuje usytuowany w środkowej części składu wagon szkolny, w którym dzieci elit nauczane są o geniuszu wybawcy ludzkości Wilforda i jego wiecznym silniku. Edukacja przybiera tu formę filmu propagandowego i kultu jednostki, ideologia reprodukuje funkcjonujące w pociągu zasady, niczym szkolny Ideologiczny Aparat Państwa ${ }^{1}$, jeden z elementów althusserowskiego Aparatu. Kiedy buntownicy wchodzą do wagonu szkolnego, dzieci traktują ich pogardliwie i nazywają „leniwymi psami, które śpią cały dzień we własnym gównie”². Wnętrze szkolnego wagonu jest wymalowane radosnymi kolorami, lecz to właśnie w nim dochodzi do drugiej z kolei masakry buntowników, tym razem z rąk ciężarnej nauczycielki. Pociąg funkcjonuje, opierając się na przemocy, niczym Represyjny Aparat Państwowy ${ }^{3}$. Elity mają na swoich usługach policjantów i żołnierzy, a nawet więzienie, które poprzedza sekcję tylną. To tam najpierw trafiają

„Ideologicznymi Aparatami Państwowymi nazywamy niektóre realności, jawiące się bezpośredniemu obserwatorowi w formie wyodrębnionych i wyspecjalizowanych instytucji. [...] Ideologia, na której oparte jest funkcjonowanie IAP, jest w istocie zawsze zunifikowaną ideologią panującą, która jest ideologią »klasy panującej«. [...] Ideologiczne Aparaty Państwowe mogą być nie tylko stawką, lecz także miejscem - często zaciekłych - form walki klas” (Althusser, nd.).

2 Lista dialogowa filmu Snowpiercer. Arka przyszłości, 2013, reż. Bong Joon-ho.

3 „W teorii marksistowskiej przez Aparat Państwowy (AP) rozumie się: Rząd, Administrację, Armię, Policję, Sądy, Więzienie, itp., które konstytuują to, co od tej chwili będziemy nazywali Represyjnym Aparatem Państwowym (RAP). [...] Rola represyjnego aparatu państwowego polega $\mathrm{w}$ istocie na tym, że jako aparat represyjny zapewnia przy użyciu siły (fizycznej lub nie) polityczne warunki reprodukcji stosunków produkcji, które w ostatniej instancji są stosunkami wyzysku" (Althusser, nd.). 
buntownicy, aby uwolnić specjalistę od zabezpieczeń, który potrafi otworzyć śluzy szczelnie oddzielające kolejne wagony, by zapobiec mieszaniu się klas. Wielokrotnie w filmie podkreślana jest konieczność zachowania ładu i przypisania do określonej pozycji w hierarchicznej strukturze. „Jestem kapeluszem, a wy butem, moje miejsce jest na głowie, a wasze na stopie. [...] Moje miejsce jest z przodu, a wasze z tyłu. Znajcie swoje miejsce! Pozostańcie na swoim miejscu! Bądźcie butem!”4 - przemawia do mieszkańców sekcji końcowej minister Mason (Tilda Swinton). Jej słowa, wsparte obrazową metaforą, potwierdzają hierarchiczny charakter przestrzeni przedstawionej w filmie Snowpiercer.

Ważnym elementem wyznaczającym podziały klasowe w przestrzeni jest $\mathrm{w}$ filmie Bonga dostęp do światła słonecznego. Tylne wagony są go całkowicie pozbawione, więc kiedy buntownicy je opuszczają, w kolejnych sekcjach po raz pierwszy od bardzo dawna widzą okna, przez które wpadają promienie słońca. Drugim ważnym elementem, jakiego brakuje gapowiczom, jest bieżąca woda. Kiedy rebelianci wydostają się z sekcji tylnej i wygrywają bitwę z siepaczami Wilforda, trafiają do wagonu uzdatniania wody, gdzie mogą się umyć. Potem idą do szklarni, w której tryska fontanna, a ogrodnicy uprawiają warzywa i owoce - kolejne produkty niedostępne dla mieszkańców ostatnich wagonów. Następnie przechodzą przez gigantyczne akwarium z morskimi rybami. Akwarium jest metaforą całego pociągu - populacja w zamkniętym ekosystemie musi podlegać ścisłej i precyzyjnej kontroli, aby nie naruszyć równowagi ekologicznej. Podobnymi prawami rządzi się społeczność Snowpiercera: liczebność pasażerów pociągu musi być stale pod nadzorem, ale nie może się to odbywać kosztem klasy pracującej lub elit, ewentualne redukcje liczebności dotyczą więc wyłącznie pasażerów ostatnich wagonów. Ich rebelia jest zatem nie tylko batalią o wolność i poprawę warunków bytowych, lecz dosłownie walką na śmierć i życie.

Film Snowpiercer: Arka przyszłości odczytywać można jako przypowieść o marksowskiej walce klas. Autor Kapitału postulował istnienie dwóch klas społecznych: burżuazji i robotników, określonych ze względu na stosunek do własności środków produkcji, między klasami toczy się nieustanna walka (Szacki 2012, 223-226). Obraz Bonga również operuje dychotomicznym podziałem pasażerów: mieszkańcy ostatnich wagonów kontra ludzie z przedniej części pociągu. Proletariat reprezentują gapowicze: przedstawiciele różnych ras i grup wiekowych. Są tu dzieci i starcy, kobiety i mężczyźni, Azjaci, biali, ciemnoskórzy, wszyscy pozbawieni możliwości samostano-

${ }^{4}$ Lista dialogowa filmu Snowpiercer. Arka przyszłości, 2013, reż. Bong Joon-ho. 
wienia i dostępu do dóbr, jakie ma do zaoferowania luksusowy pociąg. Po raz kolejny w siedemnastoletniej historii exodusu próbują przedrzeć się do silnika, by przejąć nad nim kontrolę. Przemieszczając się ku przodowi pociągu, lider rebelii Curtis (Chris Evans) powtarza, iż celem jest dotarcie do pierwszego wagonu. Poprzednie powstania upadły, gdyż nie udało im się dotrzeć do lokomotywy. Rewolucja w filmie Bonga polega więc na zawłaszczeniu przestrzeni. Ruch pociągu, podobnie jak filmowych bohaterów, jest horyzontalny, odbywa się z lewej strony do prawej, a przemieszczenie się buntowników umożliwia pokazanie kolejnych części składu. Pochód z tyłu do przodu pociągu jest również mechanizmem budowania filmowej narracji: akcja filmu Snowpiercer: Arka przyszłości zaczyna się w ostatnim wagonie, zaś kończy w pierwszym, jest wędrówką Curtisa przez cały skład pociągu, nie ma wątków pobocznych ani retrospekcji. Narracja jest tu linearna, podobnie jak przedstawiona w filmie przestrzeń. Curtis samotnie osiąga cel i jako pierwszy człowiek pokonuje całą długość składu, dlatego zasłużył, aby zająć miejsce Wilforda. Jednak kres wędrówki nie oznacza wyzwolenia, lecz jedynie nowy rodzaj niewoli, służbę silnikowi, który aby działać, potrzebuje ofiar w postaci niewolniczej pracy dzieci. Pokonawszy drogę od końca do początku pociągu, Curtis odkrywa, iż jest on więzieniem, z którego nie ma ucieczki.

\section{Wzgórza i slumsy Seulu}

Gorzką konkluzją kończy się również ostatni jak dotąd film Bonga Joon-ho Parasite, opowiadający o bezrobotnych Kimach, czteroosobowej rodzinie gnieżdżącej się w suterenie w przyziemiu. Zrządzeniem losu wkradają się do życia zamożnych Parków zamieszkujących piękny dom na przedmieściach. Biedni Kimowie oszustwem i sprytem zdobywają zatrudnienie u Parków. Kiedy syn Kim Ki-woo (Choi Woo-shik) zostaje zaangażowany jako korepetytor nastoletniej córki Park Da-hye (Jeong Ji-so), wpada na pomysł, aby umieścić w domu również siostrę (Park So-dam) jako nauczycielkę plastyki dla dziewięcioletniego Park Da-songa (Jung Hyeon-jun). Ta z kolei aranżuje zatrudnienie ojca (Song Kang-ho) na stanowisku szofera, w końcu udaje się „przemycić” również matkę (Chang Hyae-jin) jako nową gospodynię. Kiedy wszyscy Kimowie pracują już u Parków, zaczynają marzyć o zamieszkaniu w ich pięknej posiadłości. Okazuje się jednak, że ktoś ich uprzedzil. W bunkrze pod piwnicami domu od lat ukrywa się uciekający przed dłużnikami mąż poprzedniej gospodyni. 
W Parasite podobnie jak w filmie Snowpiercer: Arka przyszłości przestrzeń ma kluczowe znaczenie w definiowaniu społecznych podziałów i wyznaczaniu pola walki klas. Reżyser przedstawia najpierw ubogie mieszkanie Kimów, by następnie skontrastować je ze wspaniałą posiadłością Parków. Suterena w przyziemiu ma tylko jedno małe zakratowane okno, które znajduje się na wysokości chodnika. Mieszkańcy zamiast przyrody czy słońca widzą koła samochodów, buty przechodniów, worki ze śmieciami, a nawet oddającego mocz pijaka. W czasie dezynsekcji ulic środki owadobójcze wpadają do wnętrza, wypełniając je cuchnącym dymem. Mieszkanie jest zagracone do granic możliwości, ma nisko umieszczony sufit, panuje w nim wilgoć, wszędzie wiszą suszące się ubrania, biegają karaluchy i pluskwy. Klaustrofobiczna suterena nie daje poczucia bezpieczeństwa mieszkającej tam rodzinie, w czasie powodzi zostaje kompletnie zalana, przepada cały dorobek Kimów, zaś uszkodzona instalacja elektryczna stanowi zagrożenie dla życia.

Całkowitym przeciwieństwem ubogiego mieszkania Kimów jest dom Parków zaprojektowany przez słynnego architekta Namgoonga, który był jego poprzednim właścicielem. Posiadłość ulokowana jest na wzgórzu, co nadaje jej charakter twierdzy, poczucie bezpieczeństwa zapewniają mury, masywne bramy oraz kamery. Rezydencja ma kilka poziomów i jest otoczona zielenią. Jedna ze ścian przestrzennego salonu jest wielkim oknem wychodzącym na starannie zaprojektowany, piękny ogród. Dom jest wykończony drewnem i betonem architektonicznym, na ścianach wiszą dzieła sztuki ${ }^{5}$ i rodzinne fotografie. Wnętrza są jasne, przestronne i uporządkowane, każdy przedmiot jest na swoim miejscu. Przez wielkie okna wpada światło słoneczne, zaś po zmroku pokoje wypełniają się ciepłym światłem lamp.

Dom Parków jest w filmie Bonga nie tylko bezpiecznym, wygodnym i pięknym lokum, ale również symbolem wysokiego statusu ekonomicznego. Jest przestrzenią, którą uboga rodzina Kimów oraz gospodyni i jej mąż chcą zawłaszczyć dla siebie. Odkąd Kim Ki-woo przybywa do rezydencji, rozgrywa się tam niemal cała akcja filmu - w ten sposób reżyser narracyjnie podkreślił wagę tego domu jako obiektu pragnień bohaterów. Bong nazywa go nawet „osobnym uniwersum wewnątrz filmu” (O’Falt, nd.). Dom na wzgórzu wydaje się idealnym schronieniem. Ulewny deszcz, który literalnie zatapia mieszkanie Kimów, u Parków jest tylko nastrojowym elementem dekoracji, jak drzewa za oknem. Podczas ulewy w posiadłości na wzgórzu mały Da-song rozstawia $\mathrm{w}$ ogrodzie indiański namiot i bezpiecznie spędza w nim całą noc, podczas

5 Są to prace współczesnego artysty południowokoreańskiego Parka Seung-mo. 
gdy na dole w slumsach Kimowie w zalanym mieszkaniu z narażeniem życia walczą, by uratować choć małą część skromnego dobytku.

Sekwencja deszczu stanowi ukoronowanie konsekwentnie prowadzonej przez cały film opozycji góra-dół. Film rozpoczyna i kończy ujęcie zakratowanego okienka sutereny, przy którym suszą się skarpetki. Pod nimi siedzi Kim Ki-woo. Ta klamra kompozycyjna definiuje pozycję bohatera i wyjaśnia jego motywację do działania, desperację, z jaką młodzieniec i jego najbliżsi szukają sposobów na awans społeczny. Kimowie mieszkają na dole, więc kiedy udają się do Parków, pokonują liczne schody i wspinają się na wzgórze. W feralną noc ulewy biedacy, uciekając z rezydencji, wielokrotnie zbiegają po schodach. Dychotomia góra-dół funkcjonuje również w samej posiadłości Parków: rodzice i dzieci mają sypialnie na górze, schodzą na parter do salonu i kuchni, rzadko bywają w piwnicy, gdzie często schodzi pomoc domowa. Pod piwnicą mieści się bunkier, o którym Parkowie nawet nie wiedzą. Tam też ukrywa się mąż byłej gospodyni, a potem ojciec rodziny Kim. Nawet w tym samym domu bogaci mieszkają na górze, a biedacy na dole.

Do opozycji wertykalnej dochodzi światło, za pomocą którego reżyser podobnie jak w Snowpiercerze obrazuje podziały klasowe. Biedacy mają słaby dostęp do światła słonecznego przez małe okno tuż nad ziemią, mąż gospodyni w podziemnym bunkrze jest go całkowicie pozbawiony, podczas gdy w domu Parków przeszklona ściana i liczne okna zapewniają światło słońca przez wiele godzin dziennie. Taka aranżacja filmowej przestrzeni oparta na dychotomii góra-dół i dostępie do naturalnego światła doskonale ilustruje przedstawioną w Parasite problematykę społeczną. Bong Joon-ho przyznaje, że film ten:

jest odzwierciedleniem pogłębiającego się podziału, kategoryzacji oraz polaryzacji, która od lat dręczy mieszkańców Korei. Jest to alegoria przepaści, niemożliwej symbiozy między bogatymi i biednymi. Nasz rząd woli mieć ten problem poza zasięgiem swojego wzroku. Traktuje hierarchie klasowe jako relikt przeszłości. Ale rzeczywistość jest taka, że kapitalizm oraz gospodarka korporacyjna za każdym razem prowadzą do nieludzkich nierówności, których nie da się przezwyciężyć (Demski, nd.).

O ile Snowpiercer: Arka przeznaczenia przedstawia interpretację marksowskiego ujęcia klasy społecznej, o tyle Parasite można odczytywać z perspektywy innego klasycznego ujęcia sformułowanego przez Maxa Webera. Według autora Gospodarki i społeczeństwa istnieją trzy zasadnicze płaszczyzny zróżnicowania społecznego: ekonomiczna, w której występuje podział na klasy; prestiżu, 
w której istnieje podział na stany, i polityczna, w której mamy do czynienia z podziałem na partie. Jak stwierdza Szacka (2008, 289-290):

Wedle Webera, podział na klasy wyznacza nie stosunek do środków produkcji, ale rodzaj szans na rynku, [...] dysponowanie dobrami lub umiejętnościami pozwalającymi na osiąganie dochodów. [...] Sytuację stanową wyznacza „godność” społeczna, która wiąże się z jakąś cechą wspólną pewnej liczby osób. (Często w prezentacjach poglądów Webera zamiast określenia „godność” występuje „prestiż”). Od każdego, kto chce należeć do danego stanu, oczekuje się określonego stylu życia. Dlatego też podział na stany wiąże się ze sferą konsumpcji, gdy podział na klasy jest związany ze sferą produkcji. Z „godnością” stanową łączy się dążenie do zachowania dystansów wobec osób spoza danego stanu i skłonność do odgradzania się od nich.

Film Bonga Joon-ho ukazuje nie tylko różnice klasowe między Kimami i Parkami, ale przede wszystkim podziały stanowe. Pan domu, zamożny przedsiębiorca Park Dong-ik (Lee Sun-kyun), najbardziej ceni u swoich podwładnych zachowanie dystansu. Oczekuje od nich przestrzegania granic jego strefy komfortu i jest niezadowolony, kiedy strefę tę przekracza zapach jego szofera: „Wzrost gospodarczy wywołał »spopularyzowany elityzm«, każdy chce się wspiąć w górę, dotrzeć do elity. Co więcej, zadowolenie daje tylko sukces, motyw osiągnięć i kariery przekształca się w model dominacji” (Goban-Klas 2006, 153). Rezydencja Parków na przedmieściach Seulu jest odgrodzona murem i położona na wzgórzu, co skutecznie izoluje dom od otoczenia, nikt nieuprawniony nie przedostanie się przez bramę. Nie dochodzą tam żadne dźwięki z ulicy, wydaje się, jakby dom stał na pustkowiu, a nie $\mathrm{w}$ dziesięciomilionowej metropolii. Kiedy Parkowie wyprawiają przyjęcie urodzinowe dla syna, zapraszają na nie wyłącznie zamożnych i wyrafinowanych znajomych, ludzi swojego stanu. Troje Kimów: ojciec, matka i córka, bierze udział w uroczystości jako służba. Kim Ki-woo również jest obecny, przybył na zaproszenie zauroczonej nim córki Parków, lecz nie czuje się częścią towarzystwa z wyższych sfer, dlatego rezygnuje z dołączenia do gości w ogrodzie. Jak zauważa Szacka: „W społeczeństwach ponowoczesnych wzrasta znaczenie Weberowskich »stanów «, to jest podziałów w wymiarze kultury, opartych na różnicach systemów wartości, stylów życia i konsumpcji" (Szacka 2008, 309). Państwo Park nie jeżdżą metrem, szczególnie Park Dong-ik tego nie znosi ze względu na panujący tam zapach. Oglądamy małżonków i dzieci wewnątrz ich własnych przestrzeni: domu, samochodu, firmy, ogrodu. Przebywają w swojej enklawie, otaczają się ludźmi o podobnym statusie. 
„Moi biedni i bogaci bohaterowie myślą o sobie nawzajem jak o kosmitach” (Zaborski, nd.) - mówi reżyser.

\section{Przestrzeń życiowa, przestrzeń filmowa, pole walki}

Akcja analizowanych filmów Bonga Joon-ho rozgrywa się prawie wyłącznie we wnętrzach, zamknięte przestrzenie definiują społeczno-ekonomiczną pozycję bohaterów. Fizyczne właściwości zamieszkiwanych miejsc, jak powierzchnia, dostęp do światła słonecznego, zatłoczenie, stopień uporządkowania, określają, kim są filmowe postaci i czego pragną. Aby osiągnąć zamierzony efekt i przekonująco ukazać wpływ przestrzeni na losy bohaterów, reżyser precyzyjnie zaplanował, jak ma wyglądać scenografia w obu filmach, a następnie zbudowano ją od podstaw. W celu ukazania w obrazie Snowpiercer: Arka przyszłości dystopijnej opowieści o bohaterach uwięzionych w pociągu mknącym przez zamarzniętą Ziemię, reżyser i jego scenograf Lee Ha-jun stworzyli w czeskim studio filmowym Barrandov stumetrowy wagon ulokowany na gigantycznych żyroskopowych przegubach, by uzyskać efekt kołysania pociągu w trzech wymiarach (Barrandov, nd.). Dla podkreślenia istniejącego w filmie konfliktu klasowego reżyser umiejętnie wyważył proporcje czasu ekranowego: dokładnie w połowie czasu trwania buntownicy z sekcji końcowej przechodzą do wagonów pierwszej klasy, druga godzina rozgrywa się w „lepszym świecie”, o który walczą rebelianci pod wodzą Curtisa.

O ile wybudowanie całej scenografii w studio nie jest zaskakujące w przypadku filmu Snowpiercer: Arka przyszłości, którego akcja rozgrywa się w futurystycznym pociągu, o tyle zaskoczenie może budzić to, że mieszkanie Kimów i ulica, gdzie się znajduje, a także imponująca posiadłość Parków w Parasite również zostały wykreowane na planie filmowym. Reżyser miał bardzo precyzyjną wizję tego, jak mają wyglądać oba miejsca, i tylko wybudowanie ich od zera gwarantowało spełnienie architektonicznych warunków skomplikowanej przestrzennie opowieści. O ile suterena Kimów wzorowana była na istniejących mieszkaniach tego typu (reżyser przyznaje, że sam mieszkał w jednym z nich podczas studiów), o tyle jego odtworzenie na planie filmowym było konieczne, aby nakręcić scenę zalania mieszkania i całej ulicy przez powódź. Rekonstrukcja sutereny i jej okolic wypadła bardzo realistycznie, „nawet koreańska publiczność nie zorientowała się że scenografia została wybudowana na planie" (Wallace, nd.) - stwierdził reżyser. O wiele większym wyzwaniem było stworzenie imponującej posiadłości Parków, w której rozgrywa się 60\% akcji filmu Parasite. Lee Ha-jun próbował myśleć 
mniej jak scenograf, a bardziej jak architekt. „Musieliśmy wziąć pod uwagę czynniki filmowe, ale również stworzyć dom tak prawdziwy, żeby widownia uwierzyła, iż postaci naprawdę tam mieszkają" (Wallace, nd.) - wyjaśnia Lee.

Podczas realizacji obydwu filmów reżyser i scenograf włożyli wiele wysiłku w wykreowanie wiarygodnej przestrzeni, o którą walczą bohaterowie. Na płaszczyźnie socjologicznej do opisu owej przestrzeni pociągu czy domu oraz relacji społecznych zachodzących w ich wnętrzu można zastosować termin „pole” autorstwa Pierre'a Bourdieu:

Pole to względnie autonomiczny „mikrokosmos” wewnątrz „wszechświata społecznego", rządzący się swoistą logiką i wytwarzający właściwy sobie rodzaj praktyk i układ stosunków między uczestnikami. [...] W kategoriach analitycznych pole można zdefiniować jako sieć albo konfigurację obiektywnych relacji między pozycjami. Pozycje zaś są zdefiniowane obiektywnie ze względu na swoje istnienie i ze względu na uwarunkowania, jakie narzucają osobom i instytucjom je zajmującym, określając ich aktualną i potencjalną sytuację (situs) w strukturze dystrybucji różnych rodzajów władzy (czy kapitału). Posiadanie zaś owej władzy (kapitału) określa dostęp do specyficznych korzyści, o które toczy się gra w danym polu (Szacki 2012, 899).

Polem jest więc przestrzeń pociągu w filmie Snowpiercer, dostęp do oferowanych w nim przywilejów i luksusów, jak również przestrzeń domu Parków i prestiż przez nią symbolizowany w Parasite:

Każde takie pole jest terenem walki o zajęcie najbardziej korzystnej pozycji, tj. zdobycie przewagi nad innymi "graczami” i zawłaszczenie możliwie dużego „kapitału”, o jaki toczy się gra na danym polu. Nie jest to wszakże walka między równymi partnerami, w której liczyłyby się nade wszystko cechy osobiste jednostek, lecz walka między ludźmi i grupami społecznie usytuowanymi wyżej lub niżej, a więc przystępującymi do niej z niejednakowymi szansami i zmuszonymi do stosowania różnych strategii. Ci uczestnicy tej walki, którzy zajmują w zastanej strukturze pola pozycje uprzywilejowane, stosują strategię jej konserwacji, ci natomiast, którym przypadły pozycje poślednie lub którzy dopiero co na dane pole weszli, skłaniają się do strategii rewolucyjnych; pierwsi są wyznawcami ortodoksji, drudzy - herezji (Szacki 2012, 900).

Graczami są buntownicy z pociągu, którzy wzniecają rewolucję, aby obalić status quo ustanowione przez elity z klasy pierwszej. Grę rozgrywa także rodzina Kimów, która stopniowo wkrada się w łaski niczego nieświadomych Parków. Okazuje się, że jest także trzeci przeciwnik - gospodyni i jej mąż, 
którzy chcą dla siebie zagarnąć choćby fragment bezpiecznej przestrzeni domu. Skutki konfrontacji wszystkich trzech sił są tragiczne. Bezpieczna z pozoru przestrzeń domu zmienia swój charakter i staje się obszarem represji. W ogrodzie otoczonym murem oddzielającym od zagrożeń świata zewnętrznego dochodzi do rozlewu krwi i potrójnego morderstwa. Podziemny bunkier, będący dotychczasowym schronieniem dla męża gospodyni, staje się więzieniem dla pana Kim. Podobnie pociąg w Snowpiercerze - dla przywódcy rewolucjonistów Curtisa, którego po dotarciu do maszynowni czeka tylko praca przy obsłudze silnika. Towarzysząca mu Yona postanawia wysadzić pociąg i wyzwolić się z tyranii, mimo niepewnej przyszłości czekającej ją na zewnątrz.

\section{Przegrani zwycięzcy}

Snowpiercer: Arka przyszłości stanowi udaną próbę przebicia się kina koreańskiego do szerokiego grona odbiorców międzynarodowych. Reżyserując ekranizację francuskiej powieści graficznej, Bong Joon-ho odszedł od problematyki koreańskiej, na której do tej pory opierał się sukces artystyczny jego filmów:

Adaptacja komiksu Le Transperceneige nie traci autorskiego charakteru i stanowi naturalne rozwinięcie wątków podejmowanych przez Bonga w poprzednich filmach, ale dzięki międzynarodowej obsadzie i zdjęciom realizowanym w czeskim studio Barrandov jest filmem atrakcyjnym dla światowej widowni (Krasnowolski 2016, 28).

Snowpiercer: Arka przyszłości ze względu na swój fikcyjny charakter, dystopijny klimat i gatunkową proweniencję thrillera jest filmową przypowieścią o abstrakcyjnej walce klas. Podobną tematykę krytyki globalnego kapitalizmu reżyser podjął w swoim następnym filmie Okja, gdzie tytułowe zwierzę jest katalizatorem najgorszych ludzkich instynktów: chciwości i agresji uosabianych przez korporację, której przeciwstawia się młoda koreańska dziewczyna i jej sprzymierzeńcy, ekoaktywiści. Walka klas ma w tym filmie wymiar etyczny i ekologiczny, rozgrywa się zaś na arenie światowej. W Parasite reżyser powraca do koreańskiej tematyki, ukazując rodzimą, współczesną wersję konfliktu klasowego. „Chcę, aby publiczność poczuła, że zobaczyła uczciwe przedstawienie czasów, w których żyjemy” (Wallace, nd.) - mówi Bong, prezentując film zanurzony w południowokoreańskich realiach spo- 
łecznych i politycznych. Twórca ukazuje motyw klasowych antagonizmów na przykładzie dwóch seulskich rodzin, przy czym nie pomija także bratobójczej wojny z Północą - wprowadza wątek gospodyni i jej męża, zamieszkującego podziemny schron w willi Parków. Pomieszczenie to stanowi materialny wyraz lęku Koreańczyków przed eskalacją konfliktu z komunistycznym sąsiadem. Gospodyni parodiuje propagandę reżimu z Pjongjang, doskonale naśladując głos północnokoreańskiej spikerki, dzięki czemu jednocześnie wpisuje lęk przed agresją z Północy w tkankę codziennego życia. Dom na wzgórzu stanowi w filmie Bonga symbol trudnej koegzystencji dwóch Korei: zamożnej i nowoczesnej oraz tej zniewolonej i pozbawionej środków do życia. Stanowi kolejny dowód istniejącego tam politycznego i klasowego podziału.

W Parasite reżyserowi zależało również na realistycznym ukazaniu rozwarstwienia społeczeństwa jako skutku ubocznego koreańskiego cudu gospodarczego: „Sukces Korei ma drugą, ciemną stronę, stronę porażki w budowie harmonijnego społeczeństwa. [...] Te wszystkie zmiany przyczyniają się do [...] zwycięstwa zasady społecznego braku zaufania, nieufności, wyłączenia, rywalizacji kosztem społecznego zaufania, współdziałania i szacunku różnych warstw i grup społecznych” (Goban-Klas 2006, 153). Drapieżny kapitalizm w połączeniu z tradycją konfucjańską zaowocował modelem społecznym, w którym władza i status posiadania wyznaczają miejsce w hierarchii i definiują stosunki społeczne. W swojej teorii Bourdieu obok kapitału ekonomicznego wyróżniał także m.in. kapitał społeczny i kulturowy i opisywał ,jak dokonuje się »rekonwersja « jakiegoś rodzaju kapitału na inny jego rodzaj. [...] Pojęcie klasy, którym posługiwał się Bourdieu, różni się zgoła zasadniczo od Marksowskiego, z jego punktu widzenia w grę wchodzą bowiem różnice nie tylko i nie głównie ekonomiczne, lecz również, jeśli nie przede wszystkim, kulturowe" (Szacki 2012, 897). W filmie Bonga różnice kulturowe zarysowane zostały na poziomie drugiego pokolenia: młodzi Kimowie dają korepetycje dzieciom Parków, posiadają bowiem większy kapitał kulturowy. Chociaż żadne z nich nie studiuje, oboje dostają pracę u podejrzliwej pani Park, która uważa się za nowoczesną kosmopolitkę, w rzeczywistości jest jednak ograniczoną snobką. Aby uchodzić za bardziej światową, zwraca się do młodych Kimów wymyślonymi, amerykańskimi imionami, ci z kolei umiejętnie nią manipulują. Co ciekawe, obecność rodzeństwa oszustów wpływa jednak korzystnie na dzieci Parków, które zagubione w materialistycznym świecie rodziców samotnie zmagają się ze swoimi problemami. Ki-woo jako Kevin bardziej pomaga nastoletniej Da-hye Park przezwyciężyć nieśmiałość, niż zdać egzaminy z angielskiego, zaś Ki-jung jako Jessica dzięki swej fałszywej 
arteterapii dotyka prawdziwej traumy, jaką rok wcześniej przeżył mały Da-song. Nakreślając w swoim filmie linie społecznych podziałów, Bong Joon-ho ukazuje południowokoreańskie elity jako ludzi, których kapitał kulturowy funkcjonuje głównie w formie zinstytucjonalizowanej (dyplomy renomowanych uczelni) i uprzedmiotowionej (posiadanie pięknego domu i dzieł sztuki), przy jednoczesnym braku formy ucieleśnionej. Struktura klasowa złożona z nuworyszowskich elit ekonomicznych i walczących o awans społeczny nizin okazuje się niestabilna, co potwierdza sekwencja przyjęcia urodzinowego w ogrodzie, w której występ kwartetu smyczkowego poprzedza brutalną masakrę. W oczach Bonga koreański sukces ma gorzki smak społecznej porażki.

\section{Podsumowanie}

W swoich ostatnich filmach: Snowpiercer, Okja i Parasite Bong Joon-ho bierze na warsztat zdeterminowane ekonomicznie podziały społeczne i ukazuje je w trzech odsłonach: fikcyjnej, współczesnej i realistycznej. Wychodząc od gatunkowej paraboli, w Snowpiercerze reżyser ukazuje sztuczny świat pociągu pogrążony w walce na śmierć i życie. Z kolei w Parasite twórca obnaża społeczne koszty południowokoreańskiego cudu gospodarczego. W obydwu filmach centralne miejsce zajmuje konflikt między bogatymi a biednymi, przeradzający się w walkę klas, której celem jest zawłaszczenie nowego terytorium. Buntownicy z postapokaliptycznego pociągu i biedacy z seulskich slumsów chcą przestrzeni i wszystkiego, co wyznacza wysoką pozycję materialną i społeczną. Są gotowi o to zawalczyć z ludźmi, którzy już osiągnęli ten status. Ukazana w tych dwóch filmach walka klas nie kończy się jednak zwycięstwem, lecz nową formą zniewolenia, zaś wywalczona przestrzeń okazuje się więzieniem. Podkreśla to gorzki finał obydwu filmów: w Snowpiercerze pociąg zostaje zniszczony, większość pasażerów ginie, a przetrwanie garstki ocalałych jest niepewne, w Parasite córka Kimów, mąż gospodyni i pan Park giną, a pan Kim zostaje więźniem w posiadłości na wzgórzu. W obu obrazach klasowa rewolucja pożera swoje dzieci. Reżyser ocala najmłodszych bohaterów, by na gruzach starego porządku zbudowali nowy. Bong Joon-ho okazuje się nieprzejednanym krytykiem stosunków społecznych panujących w dobie późnego kapitalizmu. Sprawnie poruszając się po różnych filmowych płaszczyznach międzynarodowych superprodukcji i koreańskich opowieści, reżyser ukazuje społeczności rządzone przez surowe prawa ekonomii, w których status posiadania wyznacza miejsce w hierarchii. Koreańczyk wykorzystuje swój doskonały warsztat filmowy, by zaprezentować 
na ekranie przygnębiającą diagnozę naszych czasów, w których walka klas podkopuje filary społecznego zaufania i solidarności. Trafność tej diagnozy jest jednym z elementów, przesądzających o popularności jego filmów na całym świecie. Widzowie w Europie, Ameryce czy Azji odnajdują na ekranie realia, w których żyją, i bohaterów, z którymi mogą się utożsamić.

\section{Bibliografia}

Althusser, Louis. Ideologie i aparaty ideologiczne państwa. Dostęp: 30.12.2019. http://www. nowakrytyka.pl/pl/Ksiazki/Ksiazki_on-line/?id=888.

Armata, Kuba. 2019. „W świecie podziałów”. Kino 9: 45-46.

Barrandov. Production Guide Shooting with Barrandov Studios. Dostęp: 30.12.2019. http:// www.barrandov.cz/UserFiles/file/Production\%20Guide\%20to\%20Barrandov\%20 Studios\%202013.pdf.

Demski, Mateusz. Rodzina to ostatnia deska ratunku - rozmowa z Bong Joon-ho. Dostęp: 30.12.2019. https://przekroj.pl/kultura/rodzina-to-ostatnia-deska-ratunku-rozmowa-z-bong-joon-ho-ma.

Goban-Klas, Tomasz. 2006. Korea: historia i współczesność. Od pustelniczego królestwa do azjatyckiego tygrysa. Toruń: Wydawnictwo Adam Marszałek.

Krasnowolski, Marcin. 2016. „Historia sukcesu. Rozwój komercyjnego kina Korei Południowej w XXI wieku”. W Cicha eksplozja. Nowe kino Azji Wschodniej i Południowo-Wschodniej, red. Jagoda Murczyńska, 9-29. Warszawa: Korporacja Ha!art.

Krasnowolski, Marcin. 2019. „Niedoskonali bohaterowie w niedoskonałych czasach”. Kino 9: 41-44.

O'Falt, Chris. Building the 'Parasite' House: How Bong Joon Ho and His Team Made the Year's Best Set. Dostęp: 30.12.2019. https://www.indiewire.com/2019/10/parasite-house-set-design-bong-joon-ho-1202185829/.

Szacka, Barbara. 2008. Wprowadzenie do socjologii. Warszawa: Oficyna Naukowa.

Szacki, Jerzy. 2012. Historia myśli socjologicznej. Wydanie nowe. Warszawa: Wydawnictwo Naukowe PWN.

Wallace, Rachel. Inside the House From Bong Joon Ho's 'Parasite'. Dostęp: 30.12.2019. https://www.architecturaldigest.com/story/bong-joon-ho-parasite-movie-set-design-interview\#.

Wróblewski, Janusz. 17 lat dookoła świata. Dostęp: 30.12.2019. https://www.polityka.pl/tygodnikpolityka/kultura/film/1575833,1,recenzja-filmu-snowpiercer-arka-przyszlosci-rez-bong-joon-ho.read.

Zaborski, Artur. Reżyser Bong Joon-ho o świecie „Parasite”. Dostęp: 30.12.2019. https:// www.polityka.pl/tygodnikpolityka/kultura/1925398,1,rez-bong-joon-ho-o-swiecie-parasite.read. 


\title{
Architecture of Divisions. The Space of Class Struggle in Films by Bong Joon-ho: Snowpiercer and Parasite
}

\begin{abstract}
The article presents a sociological analysis of two films by Korean director Bong Joon-ho: Snowpiercer (2013) and Parasite (2019). The theoretical background is founded on two terms: social class and class struggle by Karl Marx, redefined by Max Weber and reinterpreted by Pierre Bourdieu. Also the terms of Ideological State Apparatuses and Repressive State Apparatuses by Louis Althusser are applied. All those terms form a theoretical frame within which the architectural space of Bong's films reside. The director situates the protagonists within closed spaces and class struggle, where they have to fight for survival or social advancement. By applying means of spacial description, such as density, area, orderliness, and daylight access, the director defines the protagonists' social position and their motivation.
\end{abstract}

KEY WORDs: class warfare, social class, cinematic representation, Bong Joon-ho

Agnieszka Kamrowska, (Ph.D) graduated from Film Studies at the Jagiellonian University. Researcher of Asian cinematographies. Editor of the Asian Cinema Auteurs book series. Adjunct at the Media Art Institute, Pedagogical University of Cracow. 